July 18, 2013

\title{
Extra Credit: \\ Bank Finance and Firm Export Status in Germany*
}

\author{
Stefan Goldbach \\ Volker Nitsch \\ Technische Universität Darmstadt \\ Technische Universität Darmstadt \\ and CESifo
}

\begin{abstract}
$\underline{\text { Abstract }}$
This paper estimates the exporter premium in bank lending. We examine credit relationships in Germany, covering all loans of more than 1.5 million euro over the period from 2005 to 2010. Having controlled for a wide range of other firm and bank characteristics, our results indicate that exporting firms take out loans around 15 percent larger than those of nonexporters.
\end{abstract}

JEL Code: E44; E32; G21; F40

Keywords: exporter premium; external finance; relationship lending

E-mail: goldbach@vwl.tu-darmstadt.de; nitsch@vwl.tu-darmstadt.de

* We are grateful to Heinz Herrmann for support and Matthias Köhler, Timm Körting, Peter Raupach and two anonymous referees for helpful suggestions. We thank the Deutsche Bundesbank for the provision of data and hospitality. 


\section{Introduction}

The recent literature on international trade documents (and emphasizes) sizable traderelated differences across firms. Firms not only vary strongly by trade activity; typically, only a small fraction of a country's firms engage in exports and imports. More notably, firms that export also differ significantly from non-exporters in (almost) all other relevant firm characteristics. Exporters are larger in size, more productive and pay higher wages than nonexporters; see, for instance, Bernard, Jensen, Redding, and Schott (2007). Exporters also tend to produce a wider range of products and are less likely to cease operations; see Bernard and Jensen (2007).

In this short paper, we examine the difference between exporters and non-exporters along another dimension: access to (and use of) bank credit. The dramatic decline in world trade in 2008/2009 after the bankruptcy of Lehman Brothers ('Great Trade Collapse') has led to a growing interest in the procedures of trade financing, highlighting the role of financial factors for trade activity. We aim to describe the association between finance and cross-border trade in further detail, analyzing empirically to what extent the provision of bank loans is affected by firm-specific characteristics, including the firm's export status.

Our analysis is based on a novel data set of bank-firm relationships in Germany. Specifically, we match information from the German credit register (which covers the credit exposure of banks towards individual borrowers) with detailed balance sheet data on the borrower. The resulting, newly-compiled data set has, for our purposes, three key advantages. First, the database covers all large-scale credit relationships in Germany. Since lenders are required by law to report their credit exposure with a borrower exceeding a certain threshold to the German central bank, the Deutsche Bundesbank, our results are derived from a full sample of bank-firm credit linkages. Second, due to the pair-wise structure of the credit register, the lender is properly identified. This structure allows controlling directly for bankspecific features of credit provision such as differences in lending policies or profitability. Third, the balance sheet data covers, along with other firm data, information on the borrowers' foreign sales. Based on this data, we compute measures of a firm's (aggregate) export activity.

Previewing our results, we find large exporter premia in bank lending. Our estimates indicate, for instance, that German exporting firms take, on average, 15 percent larger loans 
than non-exporters, holding constant for other factors. To the extent that we properly control for firm-specific determinants of access to external finance, these findings appear to provide broad support for the trade finance channel between banks and exporters which suggests that exports are particularly sensitive to financial conditions. Amiti and Weinstein (2011), for instance, emphasize that international trade involves higher default risk and higher working capital requirements; exporters rarely properly evaluate default risk (turning instead to banks to provide insurance) and need more working-capital financing because of long delivery times.

The remainder of the paper is organized as follows. Section 2 discusses the relevant literature. In Section 3, we describe our empirical approach and the data, followed by a presentation of the empirical results. Finally, Section 4 provides a brief conclusion.

\section{Literature}

A (by now) sizable empirical literature identifies economically large and statistically significant differences between firms that export and firms selling exclusively on the domestic market. Many studies re-examine and strongly confirm this finding for a broad range of indicators of firm activity. There are also a large number of papers which aim to replicate this observation for various countries, obtaining similarly affirmative results. ${ }^{1}$

For Germany, our country of interest, Bernard and Wagner (1997) document sizable and robust exporter premia for various plant characteristics. Based on a regional sample of firms, they find that German exporting plants are more productive than non-exporters (with a premium of about 20 percent), have a higher capital intensity (by about 12 percent) and invest more per worker (about 8 percent) than non-exporters; firms also employ more workers and pay higher wages, with the premia varying by the type of worker. Holding constant for the characteristics of both the worker and the workplace, Schank, Schnabel and Wagner (2007) estimate that employees working in a plant with an export-sales ratio of 60 percent earn about 1-2 percent more than similar employees in otherwise identical non-exporting plants. Finally, export activity is also associated with measures of firm performance and firm success; Fryges and Wagner (2010) argue that exporting has a positive causal effect on profitability.

\footnotetext{
${ }^{1}$ Given that relevant firm-level data sets often differ in design across countries and are not always readily accessible, few surveys seek to combine and summarize findings for various countries; see, for instance, Mayer and Ottaviano (2007).
} 
The role of financial variables for firm export behavior, by contrast, was initially emphasized primarily in theory. Building on the assumption that entry into foreign markets involves sunk costs, it is hypothesized that only firms with (access to) sufficient financial resources are able to start exporting. Chaney (2005) and Manova (2006), among others, formalize this idea, adding liquidity constraints to a standard heterogeneous firm model of international trade. Specifically, Chaney (2005, p. 5) argues that "one [additional] dimension of heterogeneity along which exporters may differ from non-exporters is their ability to access financial intermediaries", with less financially constrained firms being more likely to export.

The few empirical studies which aim to analyze the exporter premium for financial variables typically find evidence in support of this hypothesis. ${ }^{2}$ However, since these studies often examine measures of the financial health of firms, such as firm liquidity, they seem to provide only limited insights. For one thing, financial health, which is the most comprehensive outcome measure of a firm's business policies, depends on many factors, including the decision to export itself. In fact, given the seemingly robust finding of significant differences in financial positions between exporters and non-exporters, the empirical analysis mainly focuses on causality, with mixed results. Analyzing a panel of British manufacturing firms over the period from 1993 to 2003, Greenaway, Guariglia, and Kneller (2007) find that participation in export markets improves firms' financial health, while export starters display low liquidity. In contrast, Bellone, Musso, Nesta, and Schiavo (2010) find for a sample of French firms that exporters are already more liquid before entry, with no further growth in financial variables relative to non-exporters in the following years.

More notably, measures of financial health are, at best, only a very imperfect proxy for the variable of interest, access to external finance. For instance, a large stock of liquidity may reflect weak fundamentals rather than easy credit when firms are forced to hoard cash in times of financial constraints. As a result, the association between a firm's financial position and its access to external financial funds seems to be generally ambiguous.

\footnotetext{
${ }^{2}$ A related literature in finance explores the capital structure decisions of firms, including the use of external finance. For instance, examining a broad range of financing sources, Beck, Demirgüç-Kunt, and Maksimovic (2008) find that exporters tend to use more bank, leasing and supplier finance.
} 
The special importance of external financial conditions for international trade activities has been further highlighted in recent research on the 'Great Trade Collapse'. The sharp decline in world trade in 2008/2009 is widely attributed to a drop in the provision of trade finance by troubled financial intermediaries in the aftermath of the 2008 financial crisis. Ahn, Amiti and Weinstein (2011) provide suggestive evidence, showing that the prices of seaborne-shipped goods, which are likely to be most dependent on trade credit, rose relative to the prices of goods sent by alternative modes of transportation. In similar fashion, Chor and Manova (2012) document that countries with tighter credit markets exported less to the United States between September 2008 and August 2009, with the effect being especially pronounced in sectors that require extensive external financing; see also Levchenko, Lewis, and Tesar (2010). ${ }^{3}$ Analyzing bank-firm relationships in Japan, Amiti and Weinstein (2011) find that the health of banks providing finance affects the growth in their client's exports relative to its domestic sales.

\section{Methodology and Data}

In this paper, we aim to describe trade-related bank-firm relationships in more detail, focusing in particular on the role of external finance for foreign sales. To identify possible differences in bank lending between exporters and non-exporters, we run regressions of the following general form:

$$
\ln \left(\operatorname{Loan}_{\mathrm{ijkt}}\right)=\alpha+\beta \text { Exporter }_{\mathrm{ijt}}+\left\{\Sigma \gamma \mathrm{X}_{\mathrm{ijt}}\right\}+\phi_{\mathrm{j}}+\eta_{\mathrm{t}}+\varepsilon_{\mathrm{ijkt}}
$$

where $L_{o a n} n_{i j t}$ is a measure of the credit exposure of bank $k$ to firm $i$ in industry $j$ at time $t$, Exporter is a measure of the firm's export activity, typically a dummy variable that takes the value of one if a firm has positive foreign sales (and zero otherwise), $X$ covers a number of other firm characteristics (such as firm size), $\phi$ and $\eta$ are comprehensive sets of industryspecific and time fixed effects, respectively, and $\varepsilon$ is the residual. Bernard, Jensen, Redding, and Schott (2007) use a similar approach to quantify exporter premia for other firm characteristics. As potentially relevant firm-specific variables for lending other than export status, we consider total sales, the number of employees, firm age, equity, foreign equity holdings, and whether the firm operates more than one plant. In addition, we experiment with

\footnotetext{
${ }^{3}$ For a contrasting view, see Bricongne, Fontagné, Gaulier, Taglioni, and Vicard (2012). They find, for a sample of French firms, that the financial crisis particularly hit firms in sectors highly dependent on external finance, but conclude that the overall impact of credit constraints on trade has been limited.
} 
the inclusion of controls for firm location (federal state), the legal form of the firm, and the lending entity (bank). In our most demanding specification, we also use a comprehensive set of firm-specific fixed effects, thereby identifying the association between exports and lending from the variation in a firm's export status over time only.

We estimate equation (1) for bank-firm relationships in Germany, using quarterly data for the period from 2005 to 2010. Our main source of data is the Deutsche Bundesbank's credit register, named $\mathrm{MiMiK}$, which contains information on all loans in excess of 1.5 million euro granted by banks in Germany to firms worldwide. According to section 14 of the German Banking Act (Kreditwesengesetz), banking institutions based in Germany are required to report their large exposures on a quarterly basis to allow the central bank to monitor indebtedness; Schmieder (2006) provides a more detailed description of the database. ${ }^{4}$ For each bank-firm relationship, the size and composition of the credit exposure (both on and off balance sheet) is provided, along with the name and address of the borrower as well as information on the lender.

We match loans with (annual) balance sheet data for the borrower from the corporate balance sheets database of the Bundesbank, Ustan. The Bundesbank has collected, mainly for refinancing purposes, extensive data on individual firms; the data are primarily extracted from annual accounts and financial statements submitted directly to the Bundesbank. ${ }^{5}$ Most notably for our purposes, the database includes information on firms' export sales. Since the firm identifiers differ between the two data sets, we match the data using a propensity score matching algorithm, based on the name, the legal form and the location of the firm; see Goldbach and Nitsch (2013) for a more detailed description.

Table 1 presents a brief overview of the data. In total, the Bundesbank's credit register contains information on almost 1 million bank-firm pairs for the 24 quarters from 2005 through 2010. For the large majority of the more than 14,800 loan-taking firms in the data set, we also have complementary information on firm characteristics. In fact, we lose only about

\footnotetext{
${ }^{4}$ The German credit register was initially established in 1934, but reporting requirements were occasionally adjusted to take account of inflation (raising the regulatory reporting threshold) and structural changes in banking and financing techniques (e.g., adding credit derivatives to the definition of credit exposure).

${ }^{5}$ As Stöss (2001, p. 132) notes, these accounts are used for an examination of the creditworthiness of parties to bills of exchange, since the Bundesbank Act requires the central bank to purchase bills "backed by parties known to be solvent".
} 
20 percent of the total number of (loan-quarter) observations through our matching procedure. Most notably, the matched data set does not differ significantly from the full credit register data. For instance, the pair-wise credit exposure consistently averages at about 8 million euro.

\section{$\underline{\text { IV. Empirical Results }}$}

Firm-specific information on large-scale loans by financing entity allows identifying directly the exporter premium in external finance. Benchmark estimation results are tabulated in Table 2. Each of the four columns reports the results of a different regression specification of equation (1), gradually increasing the number of additional explanatory variables to control for differences in bank lending across firms.

Column (1) presents our default specification, in which we regress the log value of a bank's credit exposure to a firm on the export status of the borrower, holding constant for differences in lending relationships across (two-digit) industries and over time. The estimated $(\beta)$ coefficient on the exporter dummy takes a significantly positive sign; the effect is also economically large. According to our most parsimonious specification of equation (1), the point estimate of $\beta$ indicates that being an exporter tends to increase the credit exposure of a firm by, on average, about 37 percent.

The next two columns show that about one-half of this effect is explained by firm characteristics other than export participation. In column (2), we control for size, age and structure of the firm; in column (3), we additionally include fixed effects for the location and legal form of the firm as well as lender-specific fixed effects. While the estimated $\gamma$ coefficients on the auxiliary variables take on the expected sign and are statistically and economically significant, with larger and older firms taking more loans whereas multi-plant firms and firms with access to foreign capital often use alternative sources of financing, the estimated $\beta$ coefficient falls to about 0.15 . These estimates suggest that exporters take about 15 percent larger loans than non-exporters, holding other things constant.

In a final perturbation, we add to our specification a comprehensive set of firmspecific fixed effects. Since this estimator takes account of all time-invariant firm characteristics and, thus, exploits only variations in factors over time, the association between external finance and trade is exclusively identified from switches in a firm's trade activities. Unfortunately, there are only few changes in the exporter status of firms in our sample; we 
observe 23,626 episodes (of firm-bank pairs) in which a firm starts exporting and 19,797 export stops (representing, in total, a fraction of 5.4 percent of our sample of about 800,000 observations). ${ }^{6}$ Still, the estimate of $\beta$ remains positive and significant, again indicating that foreign sales are positively associated with bank lending. Specifically, the point estimate of 0.02 implies that a financial institution tends to increase its credit exposure to a firm that becomes an exporter by about 2 percentage points.

We perform extensive sensitivity analyses. Table 3 provides some of our robustness checks and extensions. Again, there are four columns (on the left of the table) which contain parameter estimates; each of these columns tabulates the result of a different regression specification, corresponding exactly to those of Table 2 . To economize on space, however, we only report estimates for the coefficient of interest $\beta$; that is, the specifications now also vary across rows such that each cell of the table presents the result of a separate regression. The column on the right of the table reports the number of observations since sample sizes differ.

We begin by varying our measure of export activity, replacing the plain export dummy with the log share of foreign sales in total sales. ${ }^{7}$ We also experiment with using employment instead of sales as our proxy for firm size or adding a separate control for firm productivity. ${ }^{8}$ Reassuringly, none of these perturbations has a qualitative effect on our results. Next, we split the sample into two sub-periods, showing that the exporter premium has become smaller since the beginning of the financial crisis. However, while the magnitude of the decline depends on the exact regression specification, our finding that exporters take out significantly larger loans than otherwise identical non-exporters remains consistently unchanged. We also split our sample along other lines. For instance, examining results by credit exposure indicates that censoring should not be an issue; the point estimates of $\beta$ turn out to be particularly strong for firms with low credit exposure. Similarly, when we divide the total credit exposure into direct credit debt and off-balance sheet liabilities the results become slightly less robust; our estimates indicate that the exporter premium in bank lending is mainly due to an exporting

\footnotetext{
${ }^{6}$ Since all firm-specific information, including data on exporting, is only available at annual frequency, we cannot identify the exact quarter of the switch in exporting status. Therefore, we attribute the switch to all (four) quarters in the year of the change.

${ }^{7}$ Before taking logs, we increase foreign sales by the value of one to deal with the problem of zero entries.

${ }^{8} \mathrm{We}$ compute a productivity measure, the ratio of value added to the number of employees, from accessible firm-level information in the Bundesbank's corporate balance sheet statistics; see also Müller and Buch (1986).
} 
firm's access to a wider range of financing instruments. The specification seems to become even more demanding, with mixed estimation results, when we use credit shares instead of credit values as dependent variable. ${ }^{9}$ Finally, our benchmark estimates remain essentially unaffected when we use lagged explanatory variables or allow for time-variant industry and bank fixed effects. ${ }^{10}$

Despite their overall consistency, our estimation results are still subject to limitations. For instance, a potential issue might be omitted variables bias. The estimated exporter premium may be mainly due to characteristics of the exporting firm (some of which are potentially unobserved) rather than the nature of the export activities, a critique that appears to be generally less relevant for our specification which includes firm fixed effects. Further, loan size may be affected by the frequency of transactions for which we have, unfortunately, no data. An obvious issue, open for future research, is to establish causality.

\section{$\underline{\text { V. Conclusions }}$}

The sudden stand-still in world trade after the collapse of Lehman Brothers in September 2008 has led to growing interest in procedures of trade finance. A growing body of evidence seems to suggest that export-related activities of firms indeed depend disproportionately on finance from external sources.

This paper contributes to this recent literature by examining differences in bank lending between exporters and non-exporters. Examining a novel data set of credit relationships in Germany covering all loans of more than 1.5 million euro over the period from 2005 to 2010, we find that exporting firms take, on average, about 15 percent larger loans than non-exporters, holding constant for a wide range of other firm and bank characteristics.

The sensitivity of export activities to the availability (and the cost) of external capital has clear policy implications. A reduction in access to trade credit (and a tightening of credit

\footnotetext{
${ }^{9}$ In particular, it should be noted that our data set covers credit exposure at the bank-firm level.

${ }^{10}$ It might be argued, for instance, that banks used primarily by non-exporters have been differently affected by the financial crisis than banks that provide finance primarily to exporting firms. We thank a referee for making this point. To deal with the extremely large number of fixed effects, we apply the algorithm from Guimarães and Portugal (2010).
} 
conditions) is likely to hit hard on financially vulnerable export industries. As a result, policy measures and interventions that improve the strength of the domestic banking and financial sector and, thereby, help avoiding financial market disruptions are expected to have a measurable impact on a country's international trade. 
$\underline{\text { References: }}$

Ahn, JaeBin, Mary Amiti, and David E. Weinstein. 2011. "Trade Finance and the Great Trade Collapse," American Economic Review. 101 (May): 298-302.

Amiti, Mary, and David E. Weinstein. 2011. "Exports and Financial Shocks," Quarterly Journal of Economics. 126 (November): 1841-1877.

Beck, Thorsten, Asli Demirgüç-Kunt, and Vojislav Maksimovic. 2008. "Financing Patterns around the World: Are Small Firms Different?" Journal of Financial Economics. 89 (September): 467-487.

Bellone, Flora, Patrick Musso, Lionel Nesta, and Stefano Schiavo. 2010. "Financial Constraints and Firm Export Behaviour,” The World Economy. 33 (March): 347-373.

Bernard, Andrew B., and J. Bradford Jensen. 2007. "Firm Structure, Multinationals, and Manufacturing Plant Deaths," Review of Economics and Statistics. 89 (May): 193-204.

Bernard, Andrew B., J. Bradford Jensen, Stephen J. Redding, and Peter K. Schott. 2007. "Firms in International Trade," Journal of Economic Perspectives. 21 (Summer): 105-130.

Bernard, Andrew B., and Joachim Wagner. 1997. "Exports and Success in German Manufacturing," Review of World Economics. 133 (1): 134-157.

Bricongne, Jean-Charles, Lionel Fontagné, Guillaume Gaulier, Daria Taglioni, and Vincent Vicard. 2012. "Firms and the Global Crisis: French Exports in the Turmoil," Journal of International Economics. 87 (May): 134-146.

Chaney, Thomas. 2005. "Liquidity Constrained Exporters,” University of Chicago.

Chor, Davin, and Kalina Manova. 2012. "Off the Cliff and Back? Credit Conditions and International Trade During the Global Financial Crisis," Journal of International Economics. 87 (May): 117-133.

Fryges, Helmut, and Joachim Wagner. 2010. "Exports and Profitability: First Evidence for German Manufacturing Firms,” The World Economy. 33 (March): 399-423.

Goldbach, Stefan and Volker Nitsch. 2013. "Cutting the Credit Line: Evidence from Germany," Darmstadt University of Technology.

Greenaway, David, Alessandra Guariglia, and Richard Kneller. 2007. "Financial Factors and Exporting Decisions," Journal of International Economics. 73 (November): 377-395.

Guimarães, Paulo, and Pedro Portugal. 2010. “A Simple Feasible Procedure to Fit Models with High-Dimensional Fixed Effects," Stata Journal. 10 (4): 628-649.

Levchenko, Andrei A., Logan T. Lewis, and Linda L. Tesar. 2010. "The Collapse of International Trade During the 2008-2009 Crisis: In Search of the Smoking Gun," IMF Economic Review. 58 (December): 214-253. 
Manova, Kalina. 2006. "Credit Constraints, Heterogeneous Firms, and International Trade," Stanford University.

Mayer, Thierry, and Gianmarco I. P. Ottaviano. 2007. The Happy Few: The Internationalisation of European Firms. Brussels: Bruegel.

Müller, Frieder and Thomas Buch. 1986. "Aufwendungen und Erträge der Unternehmen im Spiegel der Jahresabschlussstatistik der Deutschen Bundesbank und der Volkswirtschaftlichen Gesamtrechnungen - Ein Vergleich," Allgemeines Statistisches Archiv. 70: 281-305.

Schank, Thorsten, Claus Schnabel, and Joachim Wagner. 2007. "Do Exporters Really Pay Higher Wages? First Evidence from German linked Employer-Employee Data," Journal of International Economics. 72 (May): 52-74.

Schmieder, Christian. 2006. "The Deutsche Bundesbank's Large Credit Database (BAKIS-M and MiMiK," Schmollers Jahrbuch. 126: 653-663.

Stöss, Elmar. 2001. "Deutsche Bundesbank's Corporate Balance Sheet Statistics and Areas of Application," Schmollers Jahrbuch. 121: 131-137. 
Table 1: Descriptive Statistics

\begin{tabular}{|c|c|c|}
\hline & MiMiK & $\begin{array}{c}\text { MiMiK - } \\
\text { Ustan }\end{array}$ \\
\hline Loan-quarter pairs & 933,612 & 799,104 \\
\hline Firms & 14,854 & 14,545 \\
\hline of which: Exporters & & 5,839 \\
\hline Banks & 2,275 & 2,170 \\
\hline Mean loan value $(1,000 €)$ & 8,145 & 8,148 \\
\hline Median loan value $(1,000 €)$ & 2,250 & 2,305 \\
\hline Sales (bn. €) & & 8,190 \\
\hline of which: Exports (bn. $€$ ) & & 2,162 \\
\hline
\end{tabular}

Notes: The table describes samples based on the German credit register and a matched data set to which information on borrowers is added. The data cover the period from 2005-2010 in quarterly frequency. All data have been obtained from the Deutsche Bundesbank. MiMiK is the credit register; Ustan is the corporate balance sheet statistics. 
Table 2: Exporter Premium in Bank Lending

\begin{tabular}{|l|l|l|l|l|}
\hline & \multicolumn{1}{|c|}{$(\mathbf{1})$} & \multicolumn{1}{|c|}{$(\mathbf{2})$} & \multicolumn{1}{c|}{$(\mathbf{3 )})$} & \multicolumn{1}{c|}{$(\mathbf{4 )})$} \\
\hline Exporter dummy & $0.369^{* *}$ & $0.165^{* *}$ & $0.154^{* *}$ & $0.024^{*}$ \\
& $(0.008)$ & $(0.008)$ & $(0.008)$ & $(0.010)$ \\
\hline Log sales & & $0.060^{* *}$ & $0.070^{* *}$ & $0.046^{* *}$ \\
& & $(0.001)$ & $(0.001)$ & $(0.004)$ \\
\hline Log age & & $0.163^{* *}$ & $0.142^{* *}$ & 0.003 \\
& & $(0.003)$ & $(0.003)$ & $(0.029)$ \\
\hline Multi-plant dummy & & $-0.478^{* *}$ & $-0.413^{* *}$ & $0.023^{*}$ \\
& & $(0.006)$ & $(0.006)$ & $(0.010)$ \\
\hline Log foreign equity & & $-0.018^{* *}$ & $-0.009^{* *}$ & $-0.011^{* *}$ \\
holdings & & $(0.002)$ & $(0.002)$ & $(0.002)$ \\
\hline Log equity & & $0.183^{* *}$ & $0.173^{* *}$ & $-0.015^{* *}$ \\
& & $(0.001)$ & $(0.002)$ & $(0.003)$ \\
\hline Industry fixed effects? & Yes & Yes & & \\
\hline Time fixed effects? & Yes & Yes & Yes & Yes \\
\hline State fixed effects? & No & No & Yes & Yes \\
\hline Legal form fixed effects? & No & No & Yes & Yes \\
\hline Bank fixed effects? & No & No & Yes & Yes \\
\hline Firm fixed effects? & No & No & No & Yes \\
\hline & & & & \\
\hline$R^{2}$ & 0.052 & 0.103 & 0.194 & 0.730 \\
\hline
\end{tabular}

Notes: OLS estimation. Dependent variable is the log of credit exposure. Robust standard errors are in parentheses. ${ }^{* *}$ and ${ }^{*}$ denote significant at the 1 and 5 percent level, respectively. Number of observations: 799,104. 
Table 3: Robustness Checks and Extensions

\begin{tabular}{|c|c|c|c|c|c|}
\hline & (1) & (2) & (3) & (4) & (5) \\
\hline & $\begin{array}{l}\text { Industry } \\
\text { \& time } \\
\text { fixed } \\
\text { effects }\end{array}$ & $\begin{array}{l}\text { (1) plus } \\
\text { firm- } \\
\text { specific } \\
\text { variables }\end{array}$ & $\begin{array}{l}\text { (2) plus } \\
\text { state, legal } \\
\text { form \& } \\
\text { bank fixed } \\
\text { effects }\end{array}$ & $\begin{array}{l}\text { (3) plus } \\
\text { firm fixed } \\
\text { effects }\end{array}$ & $\begin{array}{l}\text { Number } \\
\text { of } \\
\text { observa- } \\
\text { tions }\end{array}$ \\
\hline Baseline & $\begin{array}{l}0.369 * * \\
(0.008)\end{array}$ & $\begin{array}{l}0.165^{* *} \\
(0.008)\end{array}$ & $\begin{array}{l}0.154 * * \\
(0.008)\end{array}$ & $\begin{array}{r}0.024^{*} \\
(0.010)\end{array}$ & 799,104 \\
\hline $\begin{array}{l}\text { Substitute log export } \\
\text { share for exporter } \\
\text { dummy }\end{array}$ & $\begin{array}{l}1.138^{* *} \\
(0.020)\end{array}$ & $\begin{array}{l}0.429 * * \\
(0.020)\end{array}$ & $\begin{array}{l}0.401 * * \\
(0.020)\end{array}$ & $\begin{array}{l}0.106^{* *} \\
(0.030)\end{array}$ & 799,104 \\
\hline $\begin{array}{l}\text { Substitute log } \\
\text { employment for log sales }\end{array}$ & $\begin{array}{l}0.369 * * \\
(0.008)\end{array}$ & $\begin{array}{l}0.190 * * \\
(0.008)\end{array}$ & $\begin{array}{l}0.186 * * \\
(0.007)\end{array}$ & $\begin{array}{c}0.016 \# \\
(0.010)\end{array}$ & 799,104 \\
\hline $\begin{array}{l}\text { Adding log firm } \\
\text { productivity }\end{array}$ & $\begin{array}{l}0.365^{* *} \\
(0.008)\end{array}$ & $\begin{array}{l}0.165^{* *} \\
(0.008)\end{array}$ & $\begin{array}{l}0.159 * * \\
(0.008)\end{array}$ & $\begin{array}{r}0.016 \# \\
(0.010)\end{array}$ & 763,272 \\
\hline Before Q3/2008 & $\begin{array}{l}0.358 * * \\
(0.010)\end{array}$ & $\begin{array}{l}0.183 * * \\
(0.010)\end{array}$ & $\begin{array}{l}0.184 * * \\
(0.010)\end{array}$ & $\begin{array}{c}0.012 \\
(0.014) \\
\end{array}$ & 442,660 \\
\hline After Q2/2008 & $\begin{array}{l}0.383^{* *} \\
(0.012)\end{array}$ & $\begin{array}{l}0.146^{* *} \\
(0.011)\end{array}$ & $\begin{array}{l}0.123 * * \\
(0.011)\end{array}$ & $\begin{array}{c}0.005 \\
(0.015)\end{array}$ & 356,444 \\
\hline $\begin{array}{l}\text { Credit exposure below } \\
2 \mathrm{~m} €\end{array}$ & $\begin{array}{l}0.175^{* *} \\
(0.011)\end{array}$ & $\begin{array}{l}0.218^{* *} \\
(0.011)\end{array}$ & $\begin{array}{l}0.253^{* *} \\
(0.010)\end{array}$ & $\begin{array}{l}0.039 * * \\
(0.015)\end{array}$ & 364,725 \\
\hline $\begin{array}{l}\text { Credit exposure above } \\
2 m €\end{array}$ & $\begin{array}{l}0.098 * * \\
(0.004)\end{array}$ & $\begin{array}{l}-0.036^{* *} \\
(0.004) \\
\end{array}$ & $\begin{array}{l}-0.064 * * \\
(0.003) \\
\end{array}$ & $\begin{array}{r}0.009^{*} \\
(0.004) \\
\end{array}$ & 434,379 \\
\hline $\begin{array}{l}\text { Use on balance sheet } \\
\text { credit as regressand }\end{array}$ & $\begin{array}{l}0.078^{* *} \\
(0.010)\end{array}$ & $\begin{array}{l}-0.001 \\
(0.010)\end{array}$ & $\begin{array}{l}0.035^{* *} \\
(0.010)\end{array}$ & $\begin{array}{l}0.047 * * \\
(0.012)\end{array}$ & 799,104 \\
\hline $\begin{array}{l}\text { Use off balance sheet } \\
\text { debt as regressand }\end{array}$ & $\begin{array}{l}0.536^{* *} \\
(0.009)\end{array}$ & $\begin{array}{l}0.418^{* *} \\
(0.009)\end{array}$ & $\begin{array}{l}0.332 * * \\
(0.009)\end{array}$ & $\begin{array}{c}0.004 \\
(0.009)\end{array}$ & 799,104 \\
\hline $\begin{array}{l}\text { Use log credit/total debt } \\
\text { ratio as regressand }\end{array}$ & $\begin{array}{l}-0.025 * * \\
(0.001)\end{array}$ & $\begin{array}{l}0.003 * * \\
(0.000)\end{array}$ & $\begin{array}{l}0.006^{* *} \\
(0.001)\end{array}$ & $\begin{array}{l}-0.001 \\
(0.001)\end{array}$ & 799,104 \\
\hline $\begin{array}{l}\text { Use log credit/total } \\
\text { assets ratio as } \\
\text { regressand }\end{array}$ & $\begin{array}{l}-0.020 * * \\
(0.001)\end{array}$ & $\begin{array}{l}0.003 * * \\
(0.000)\end{array}$ & $\begin{array}{l}0.004^{* *} \\
(0.001)\end{array}$ & $\begin{array}{l}-0.000 \\
(0.001)\end{array}$ & 799,104 \\
\hline $\begin{array}{l}\text { Lagged explanatory } \\
\text { variables }\end{array}$ & $\begin{array}{l}0.361 * * \\
(0.008)\end{array}$ & $\begin{array}{l}0.162 * * \\
(0.008)\end{array}$ & $\begin{array}{l}0.144 * * \\
(0.008)\end{array}$ & $\begin{array}{c}0.007 \\
(0.011)\end{array}$ & 653,281 \\
\hline $\begin{array}{l}\text { Use industry-time and } \\
\text { bank-time fixed effects }\end{array}$ & $\begin{array}{l}0.370^{* *} \\
(0.008)\end{array}$ & $\begin{array}{l}0.167 * * \\
(0.008)\end{array}$ & $\begin{array}{l}0.156^{* *} \\
(0.007)\end{array}$ & $\begin{array}{r}0.029^{*} \\
(0.013)\end{array}$ & 799,104 \\
\hline
\end{tabular}

Notes: OLS estimation. Robust standard errors are in parentheses. ${ }^{*}, *$ and \# denote significant at the 1, 5 and 10 percent level, respectively. Other regressors, analogous to the specifications in Table 2, included but not reported. 


\section{Appendix: Description of Variables}

\begin{tabular}{|c|c|c|c|}
\hline Variable & Description & Mnemonic & Source \\
\hline Credit exposure & $\begin{array}{l}\text { Total liabilities (including on balance sheet } \\
\text { credit exposure, off balance sheet credit } \\
\text { exposure, derivatives, and debt guarantees) } \\
\text { at the end of the quarter }\end{array}$ & gesamt & MiMiK \\
\hline $\begin{array}{l}\text { On balance sheet } \\
\text { credit exposure }\end{array}$ & $\begin{array}{l}\text { Liabilities that have to be reported on } \\
\text { balance (e.g., credits, bonds) }\end{array}$ & forderungen & MiMiK \\
\hline $\begin{array}{l}\text { Off balance sheet } \\
\text { credit exposure }\end{array}$ & $\begin{array}{l}\text { Liabilities that do not have to be reported } \\
\text { on balance (e.g., securitized assets) }\end{array}$ & außerbilanziell & MiMiK \\
\hline Exports & Export sales & AP30 & Ustan \\
\hline Sales & $\begin{array}{l}\text { Total sales (without value added tax and } \\
\text { after sales deduction) }\end{array}$ & AP144 & Ustan \\
\hline Employment & $\begin{array}{l}\text { Average number of employees during the } \\
\text { business year (or, alternatively, at the date } \\
\text { of account) }\end{array}$ & AP34 & Ustan \\
\hline Productivity & $\begin{array}{l}\text { Value added (gross profit minus rental and } \\
\text { lease expenses minus other operating } \\
\text { expenses minus taxes) divided by the } \\
\text { number of employees }\end{array}$ & $\begin{array}{l}\text { (AP153- } \\
\text { AP161- } \\
\text { AP162- } \\
\text { AP159)/AP34 }\end{array}$ & Ustan \\
\hline Age & $\begin{array}{l}\text { Year of financial statement minus } \\
\text { establishment year }\end{array}$ & AGJ-AP7 & Ustan \\
\hline Multi-plant firm & $\begin{array}{l}\text { Annual financial statement is included in a } \\
\text { consolidated financial statement }\end{array}$ & AP36 & Ustan \\
\hline $\begin{array}{l}\text { Foreign equity } \\
\text { holdings }\end{array}$ & Foreign equity capital & AP32 & Ustan \\
\hline Equity & Equity capital & AP137 & Ustan \\
\hline Debt & $\begin{array}{l}\text { Total debt (sum of short-term debt and } \\
\text { long-term debt) }\end{array}$ & AP111+AP128 & Ustan \\
\hline Assets & Total assets (balance sheet total) & AP88 & Ustan \\
\hline Industry & $\begin{array}{l}\text { Industry classification (WZ 2003) at the 2- } \\
\text { digit level }\end{array}$ & AP20 & Ustan \\
\hline Legal form & Legal form & ARECHT & Ustan \\
\hline State & $\begin{array}{l}\text { Federal state (by postal code of firm } \\
\text { headquarter) }\end{array}$ & AP9 & MiMiK \\
\hline
\end{tabular}

